\title{
Intercultural practicum: Perceptual learning through video in the pandemic context
}

New Zealand Journal of Teachers' Work, Volume 17, Issue 1 \& 2, 56-72, 2020

\author{
DAWN JOSEPH \\ Deakin University, \\ Melbourne, Australia \\ RICHARD JOHNSON \\ RMIT University, \\ Melbourne, Australia
}

\begin{abstract}
In our work with Australian initial teacher education (ITE) students our emphasis is on encouraging students to understand different cultural practices. Drawing on narrative reflection, we discuss intercultural and pedagogical concerns in which ITE students undertake international practicums (school placements). We recognise these students have a predominantly Western lens when undertaking practicums in Asian countries. To address this issue a video A Day in the Life... of Tamil School Children (https://youtu.be/vPdiogRR-Ig) in India was produced to change, improve and help students learn about the social and cultural environment of the 'international student'. Students who took part in previous international practicums agreed that the video was an effective tool for cultural familiarisation. During this time of COVID-19 with travel restrictions abroad, the video resource serves as an effective visual pedagogy to build cultural understanding, embrace diversity, enable perceptual learning and empower students to cultivate intercultural understandings of the other'.
\end{abstract}

\section{INTRODUCTION}

There is much to applaud in the move to internationalisation in higher education where the focus is to promote international student recruitment, build research collaborations and capacity building (Bodycott, 2009; Knight 2004; de Wit, 2020). Internationalisation is seen to be predominantly about growing relationships and interactions between national entities and cultures (Marginson \& Considine, 2000; Scott, 1998). It can also be described as "establishing international communities through student and staff mobility" (Bridges \& Bartlett, 2005 , p. 102). Internationalisation is more than a varied and all-encompassing concept that replaces a Western paradigm, rather, key changes have impacted internationalisation in its broadest context in relation to its "massification, global knowledge economy and the emphasis on reputation and rankings" (de Wit, 
2019 , p. 10). All universities welcome international students and state that they promote a global perspective to the curriculum. The COVID-19 pandemic has, however, dealt Australasian and other universities a crippling blow by cutting off their supply of international students, thus exposing their financial dependence on them. As will be argued in this article, there is a need to take a closer look at our Asian neighbours with a more reflexive view to learn, understand and develop a greater appreciation of what they can offer us in relation to cultural exchanges. It would be refreshing to build relationships that are not based on financial gain but grounded in "understanding of social justice, empathy and interculturality" (Jackson, 2018, p. 135). While it is beyond the scope of this article to focus on internationalisation, we (Dawn and Richard) acknowledge the popularity and importance of international practicums (school placements) within initial teacher education (ITE) programmes in Australia.

We work in ITE programmes at two different universities in Melbourne and between us have 60 years of tertiary teaching experience. Part of our job as tertiary educators is preparing our ITE students to meet the Australian Institute for Teaching and School Leadership (AITSL) standards which require them to be able to teach "students with diverse linguistic, cultural, religious and socio-economic backgrounds" (AITSL, 2020). Over the years, we have discussed the cultural disconnection that occurs when our Anglo-Australian students work with students and staff from non-Western cultures, countries and ethnicities, especially given our position as academics of colour. Our attraction to this area eventuated in an article that drew on critical race theory, where we highlighted the importance and need to understand and embrace differences in the academy (Joseph \& Johnson, 2019). This article focuses on our on-going reflections on the intercultural and pedagogical concerns we have when ITE students undertake practicums in predominantly Asian countries.

Having experienced cultural differences as academics in our teaching, we discuss in this article ways in which to help prepare ITE students understand their cultural experience when going out on practicums. An important aspect of this preparation is building intercultural competencies that include "respect, listening, curiosity, self-and other awareness, reflection, sharing, empathy, and relationship building (Deardoff, 2020, p. 14). In preparing ITE students for the profession, the focus is on building intercultural understandings as part of general capabilities outlined in the Australian curriculum (ACARA, 2020). Intercultural understanding involves students "learning about and engaging with diverse cultures in ways that recognise commonalities and differences, create connections with others and cultivate[s] mutual respect" (ACARA, 2020). We both taught at the same university for ten years, before Richard moved to RMIT University in 2010. When preparing for practicum in India and Nepal, he found that his students were concerned that they lacked the content knowledge required to teach in their host school. This indicated to us that cognition and the acquisition of knowledge was the focus of our teacher education courses. Students discussed acquiring relevant cultural and religious knowledge through reading, favouring the cognitive methods of learning and neglecting the experiential and perceptual. Therefore, the idea of preparing a video focusing on the culture of the host children seemed an appropriate resource for ITE students to experience, explore, and engage in discussion with the lecturer and their peers prior to undertaking their placement. Here we discuss why it is important for our ITE students to be introduced to the social and cultural 
environment of the international learner employing a visual narrative methodology. Using a video is one option to consider for competency development, one that goes beyond visual media and cultural products that includes 'visuality' in relation to what is seen and how it is seen (Pauwels \& Mannay, 2020). The video A Day in the Life ... of Tamil School Children was scripted (with critical assistance from Dawn) and produced by Richard. The Video was filmed by Verandah Entertainment in 2016 (Chennai, India). The video is available on YouTube (https://youtu.be/vPdiogRR-lg) and is publicly accessible online. The storytelling in the video is used as a visual methodology to stimulate discussion for ITE students to "learn to value and view critically their own cultural perspectives and practices and those of others through their interactions with people, [and] texts" (ACARA, 2020). The video relates to the creation of the storyline that is engaging to viewers in relation to events that take place, and memories it creates for the viewer which leads to interpretation (Comet, 2018).

Richard is formerly from India and has lived in Australia since 1969. Dawn has never been to India; she is formerly from South Africa of Indian heritage (Joseph, 2010). She has lived and worked in Australia for the past two decades. She contributes to this article as a colleague who has written widely in the area of promoting and fostering of intercultural understandings in ITE programmes (Joseph, 2003, 2016; Joseph \& Human, 2009; Joseph, Nethsinghe, \& Cabedo-Mas, 2018). In this article, we argue the need to culturally prepare ITE students when undertaking placements in India or in any other developing economies, particularly in Asia.

The video that is central to this article, was designed to represent the cultural narratives of two Tamil children in their home environment in Chennai, India. The Tamil language was chosen because it was unlikely that any of the Australian students would have heard Tamil before. It was scripted and choreographed to include subtle, nuanced cultural behaviour common to the local community and yet likely to go unnoticed by the Westerner confounded by the maelstrom of the sounds and smells of India when on location. The video could have been in many other similar locations in other parts of Asia. By embedding the video in pedagogy (Blomberg et al., 2014), Australian ITE students are encouraged to develop their intercultural understandings and consider their sense of self and their own identity before undertaking an international placement. The video as a form of storytelling is central in building intercultural competencies. It cultivates curiosity about similarities and differences with others and it increases cultural self-awareness in the hope of developing empathy with culturally different others (Deardoff, 2020). The video is prepared as a social and cultural activity to develop intercultural competencies which is aimed to generate new understandings and insights. We seek to encourage ITE students to avoid pathologising the Asian 'other', and instead, to see learners within their social and cultural environments and critically examine the assumption that 'West is best'. Within this is a noteworthy phenomenon that is not openly discussed and presents itself in countries like India and Nepal, and often in other Asian countries where the 'worship of the white' by local people is significant (Abraham, 2017; Dhillon, 2012).

Australia remains a popular destination for international students to study (Smith, 2014). While Melbourne has a large Asian population, Topsfield (2016) points out that students seem uncomfortable undertaking overseas practicums 
with their Asian neighbours. We propose that they would benefit from having an informed Asian cultural and pedagogical experience in a more reflexive and deeper way before undertaking placements when the host country is not first world, white, or Western. The intercultural and pedagogical concerns in this article are based on reflections from previous research projects in Asia (see Johnson, 2009; Johnson \& Jumani, 2009;).

Drawing on narrative inquiry, our collaboration has evolved over time in our workplaces (Clandinin \& Connelly, 2000). We reflect in and on our pedagogy in regard to preparing ITE students for placements and future classrooms (Bulman \& Schutz, 2004; Kember, 2001; Schön, 1983). We adopt a visual narrative methodology (Blomberg et al., 2014; Ridgway et al., 2016) as an intentional and reflective pedagogical opportunity for ITE students. In this way students can explore and make meaning of the experience both visually and narratively. Pauwels and Mannay (2020) make the point that gaining an understanding of culture and society can be developed through seeing, observing, exploring and theorising the visual and noticeable behaviour of people and culture. By viewing the video and through class discussion, students may gain a deeper understanding of the host placement, and may also come to appreciate the rich cultural, linguistic and religious diversity of Australia. The Australian curriculum calls for students to develop intercultural understandings by valuing their own "cultures, languages and beliefs and those of others" and by "learning about and engaging with diverse cultures in ways that recognise commonalities and differences, create connections with others and cultivate mutual respect" (ACARA, 2020). In this article we contend that the proposed video serves as an effective starting point for discussion when ITE students prepare for international placements such as India. The video may also serve to enhance students' general capabilities that addresses intercultural understandings (ACARA, 2020). We welcome international dialogue concerning how best to prepare ITE students for international placements. We hope that our article adds to the body of research in this area by creating and sharing multimodal narratives in a global, networked community to act as "intercultural triggers" that generate cross-cultural communication. (Hull et al., 2010, p. 361).

\section{THEORETICAL UNDERPINNINGS}

\section{Building cultural understanding}

In our work with ITE students, our emphasis is on encouraging students to understand that different cultural practices do not mean determining which one is right or best (Rogoff, 2003). Rather, it means embracing other cultures without abandoning one's own and disregarding the other. Preparing students as ITE graduates also means gaining cultural competence. Cultural competence is not easy to define according to Frawley et al. (2020). They point out it is a journey about behaviours and attitudes, knowing and understanding, and respecting and valuing difference in relation to one's own history, traditions, beliefs and practices. Therefore, cultural competence means being able to teach students from different cultures other than your own (Diller \& Moule, 2005). It also means that "teachers who are prepared to help students become culturally competent are themselves culturally competent; they know enough about students' cultural and individual life circumstances to be able to communicate well with them" (Ladson-Billings, 2001, p. 97). While cultural 
competence is central to our pedagogy, ITE students are required to understand their own and their students' social practices to improve relationships across cultures (Johnson \& Jumani, 2009; Joseph, 2016; Joseph et al., 2018; Joseph \& Johnson, 2020). In the context of ITE, cultural competence involves building "positive dispositions toward diversity, and a reflective cultural knowledge base (self-knowledge as a sociocultural being and other people's cultural worldviews and systems)". It also means creating a space that "embodies a sense of humility, openness, and comfort in seeking and sustaining cross-cultural interactions and relationships" (Ukpokodu, 2011, p. 437). The implications of these practices contribute to learning about others and understanding that learning is shaped by one's own cultural background. Making meaning enables educators to construct a way of seeing how all people learn through the prism of their everyday understandings (Howard \& Aleman, 2008). Once this more complex understanding of culture is developed, teachers can begin to see themselves and their students as cultural beings and understand how teaching practices are culturally derived practices in school (Carter \& Darling-Hammond, 2016). Teachers need to be prepared to be a 'cultural broker' one who "thoroughly understands different cultural systems, is able to interpret cultural symbols from one frame of reference to another, can mediate cultural incompatibilities, and knows how to build bridges or establish linkages across cultures that facilitate the instructional process" (Gay, 1993, p. 293).

We draw on conceptions of intercultural philosophy (Besley \& Peters, 2012) which has effectively shifted the discourse away from notions of culture, to notions of hybridisation, institution of cultural exchange and a critique of liberal cosmopolitanism. The inherent openness of this conception and the emphasis on the cultural 'other' is a central issue in this article in relation to Australia's relationship with our Asian neighbours. Intercultural philosophy assumes that exposure to engagement with different cultures will encourage a greater understanding of the world's peoples in all their ethnic and cultural diversity, and thereby also provide the basis for intercultural understanding and dialogue.

Whilst Australia is a multicultural society, it is surprising how predominantly Western the lens or prism is through which 'the other' is experienced (O'Brien, 2016). It is our observation that in tertiary teaching we typically address intercultural understandings with resources most readily available to us, which tend to be set in a European context. As we re-examine teacher education through the lens of inclusivity and intercultural philosophy, we explore other enlightenments or an alternative modernity (Feenberg, 1995).

There is a cogent case for discussing alternative resources that may be used in developing an inclusive curriculum. There are Eastern resources relating for example to an Indian Enlightenment period, which are accessible and can demonstrate alternative lenses for examining the concepts of sameness and difference in developing an understanding of childhood and adolescence.

Understanding the Indian approach to education is part of a large collection of sacred books of the Hindu people, called the Vedas. In Hindu educational practice, the Upanishads are concerned with 'Shravana', 'manana', and 'nididhyasana' (Mookerji, 1969). Shravana refers to "the process of listening to one's teacher and listening to the oral tradition on which the Hindu religious 
tradition is largely based" (Reagan, 2000, pp. 139-140). It is the Shravana that provides the content base necessary for a person to become educated. Shravana is followed by manana, which involves reflection on that which is contained in the Shravana. Manana is best understood as the process by which one begins to think about the meaning of what one has learned and is essentially an intellectual rather than a spiritual process. Manana is followed by nididhyasana or meditation, in which the goal is the realisation of truth and the "consciousness of the one." (Mookerji, 1969, pp xxxi-xxxiii). Each, in its own way, reflects all the different traditional Hindu educational practices that follow this same general process of increasing spirituality (Reagan, 2000).

These educational and cultural influences are demonstrated in the prepared video A Day in the Life ... of Tamil School Children, as a way to shed understanding for students. Making such a resource from the region prominent is relevant to the practicum visit. It increases understanding and seeks to demystify all forms of xenophobia, racism and cultural stereotyping. The video is a means by which to promote better cultural relations and understandings through perceptual learning. In this article, we use our video as part of our research method to disseminate the results of our findings which we believe go beyond the power of text to convey the importance of perceptual learning in an intercultural context. We use our video in this context to engage the learner to experience the culture first-hand before they leave on placement for example (Walker \& Boyer, 2018). In our work with the video we discuss 'looking at, seeing, and interpreting' as notions of Chalfen's (2011) use of video in research methods. We discuss how we look at ourselves and the world around us and what we see before us as opposed to being aware of our culturally determined way of looking at and interpreting 'the other'.

\section{Pedagogy of perceptual learning}

Perceptual learning is an active engaging process that involves looking and listening (Carey, 2014). It looks at how learners extract information from their surroundings using their five senses (Davis, 2007). Perceptual learning is self-regulated in the sense that modification occurs without the necessity for external reinforcement. It is stimulus-oriented, with the goal of extracting and reducing the information simulation. Discovery of distinctive features and structure in the world is fundamental to the achievement of this goal. The field of research on perceptual intent challenges the widespread belief that perceptual learning happens 'automatically' without trying (Brandimonte et al., 1996). It has the potential to transform training in many areas of study and expertise (Carey, 2014). Part of the difficulty of pursing an intercultural understanding agenda within an educational setting has been the lack of conceptual clarity and precision as to what specific competencies are teachable and what the assessment framework might be for testing such pedagogic approaches (Besley \& Peters, 2012).

We argue for the need to purposefully focus on the perceptual skills of teaching and learning when preparing ITE students for international placements. The intent of the video is to address the development of perceptual learning skills using video, challenging students to engage with learning that is not necessarily cognitive (Johnson, 2017). The adage that 'good teachers have eyes at the back of their heads' is worth noting in this international context. The question here is, how do ITE students develop the awareness and appreciation 
of observing and recognising relevant cultural cues in the environment? Educators generally believe that this cannot be taught. The belief is that you learn this on the job as your awareness and experience is widened. In a rich and diverse international environment, developing perceptual skills to appreciate the whole learning environment is a challenge when preparing ITE students on placements. The use of the video is to stimulate pedagogical awareness as a discussion point. It offers students a perceptual learning experience in a cultural context that is one beyond Bodily-Kinaesthetic, VisualSpatial and Emotional dimensions (Gardner, 2006).

\section{Rationale of the video}

By adopting a visual narrative methodology, the video served as a pedagogical opportunity of inquiry from design to production to analysis (Mannay, 2015). This methodological perspective asserts that the 'classroom video' is an effective tool for ITE, when embedded in an instructional programme. It is an intentional, reflective process in which researchers and participants explore and make meaning of the experience both visually and narratively (Blomberg et al., 2014; Ridgway et al., 2016). The video was made as a teaching and learning tool based on our observations that students have two main channels for learning: what they see and what they hear. Videos were found to work much better than books, websites, or podcasts, because these only use one channel whereas video uses both. On video, teachers can edit themselves to best use both channels by showing useful visuals that are perfectly timed to the spoken explanation (Noetel et al., 2020). In the current pandemic environment online leaning and teaching has become the focus of much attention, in particular the use of video in pedagogy (Noetel et al., 2020).

Selecting media seemed an effective way for ITE students to absorb the content and make cultural connections in relation to how instruction and learning take place. The need to experience societal, cultural, and social interactions of the international student forms an important aspect of the immersion process for the ITE student. John Dewey's (1963) notion of using experience as a teaching tool is especially important in providing guidance to the students in their observation and judgement in selecting experiences that have promise and potential for their understanding of Asian cultures for example. The video provides ITE students with the opportunity to immerse themselves in the social and cultural environment of the learner and gain an insight into the social and cultural environment of the learner. As a cultural artefact the video serves as a "media of consciousness" (Holland et al., 1998, p. 63). It gives rise to higher mental functions and self-reflexivity where deeper critique is needed in understanding the international student in relation to the Australian ITE student's Western culture and identity

\section{THE VIDEO: 'A DAY IN THE LIFE... OF TAMIL SCHOOL CHILDREN'}

The video represents the narrative of two young Indian children in the rich cultural environments of home and school in Chennai, in the State of Tamil Naidu. The video was designed to better prepare students by immersing them in a cultural environment that they may not usually admire. It was aimed at better preparing students to gain a greater appreciation of the new place, and to learn from the video how children get ready for the school day. The video 
fosters a sense of equality, human dignity and common purpose. It aims to develop "a deeper understanding of diverse worldviews and practices, to increase co-operation and participation to allow personal growth and transformation, and to promote tolerance and respect for the other" (Council of Europe White Paper, 2008, p. 9). The purpose of the video is for our students to understand their own culture, and through viewing the video, discuss even their 'naïve questions' with their lecturer to deepen their understandings of other cultures (Leeds-Hurwitz, 2013). The video depicts the local children functioning in their everyday home and school environment speaking their home language, Tamil (with English sub-titles). The video follows two students, Jenolin and Suhela on an average school day with many of the rich cultural nuances of everyday life. Tamil was chosen as the language because it would most likely be unfamiliar to the majority of white Anglo-Saxon monolingual students. Through embedding the video in pedagogy (Blomberg et al., 2014), the ITE students are meant to develop an appreciation of Indian culture before embarking on their practicum experience. It is anticipated that the ITE student will develop and use a cultural learning narrative that will be influenced by the richness of their home culture as they reflect on their development of self as part of the whole learning experience.

Richard used the video with his students as part of the pre-departure preparation. The discussion that followed was about being respectful of other cultural groups, and embracing difference with admiration and esteem (Rizvi, 2010). It cannot, however, be assumed that this will happen automatically.

The video is a starting point to focus on looking at ourselves in relation to what is important to us in the world around us. It also promotes dialogue about who we see, hear and smell, and prepares us to look at and interpret 'the other' with understanding and respect for what is important to them (Chalfen, 2011). Drawing on the inspiration of Rosenblum, (2010), we argue that it is important to us as tertiary educators to purposefully develop our five senses of touch, sight, smell, hearing and taste. Rosenblum's (2010) research shows how our brain and sensory perception can be influenced by what we perceive without even noticing. Our purpose is to make our ITE students aware of the sensory antennas of the cultural environment of their hosts and to be respectful of and attentive to them.

Students are given the opportunity to view the video after a discussion of the importance of perceptual skills in learning. The Venn diagram below (Fig. 1) represents three principal areas of focus of perceptual learning, auditory (hear), visual (see), and tactile (touch). The idea behind this method is that with regular practice and awareness, individuals can sharpen their listening skills to the extent where it occurs apparently without the need for thought (Terry, 2000). The emphasis on the non-cognitive and sensuous dimensions of learning as a simulation is an important aspect of perceptual learning (Carey, 2014). 


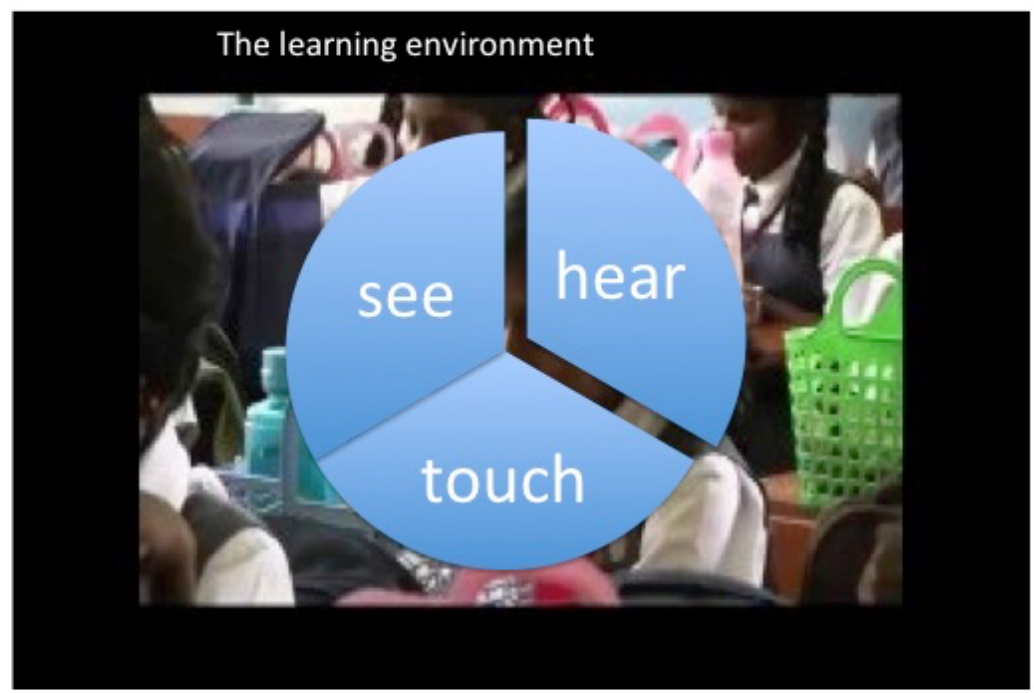

Fig.1: Perceptual learning environment

Students are invited to reflect on and research the learning environment represented in the video. This can be done at several levels and to a depth that is appropriate. Students tend to research comparative questions and therefore need to be directed by suggested observational prompts to better form the scaffolding for learning that leads to a greater openness to the overseas learning environment. It cannot be taken for granted that teacher education students will have perceptual learning skills in relation to teaching.

Video methodology presents an opportunity to introduce a discussion of the importance of the perceptual skills in visual, auditory and tactile areas. It is important for the ITE students to be aware of the unfamiliar intercultural elements of learning and teaching. Video methodology may achieve such a pedagogical purpose by offering opportunities for noticing nuances of cultural difference (Sherin \& Russ, 2014).

\section{A PERCEPTUAL LEARNING FRAMEWORK}

Video methodology supports the development of the perceptual learning environment depicted in Fig. 1. Beginning with auditory skill development, it is recommended that a viewing is made to observe the various sounds of the local setting. The video begins with the sound of a car horn, providing an opportunity to stimulate the discussion with 'iconic sounds'. This is illustrated by noncognitive learning through prompts. For example:

- What do the car horn sounds signify?

- What are the other distinctive sounds throughout the video?

- Why is it important to sharpen the ability to be alert to every sound in the teaching environment? 
In the Indian context, the sound of the car horn is a form of communication. As such, the sounds of the street, the schoolyard and the classroom are all auditory communication cues and messages. The language spoken in the video (Tamil with English sub-titles) raises students' awareness of the sound of language and the different 'families of languages' based on sound. For instance, students could be shown a commercial Tamil film such as 'Dharmadurai' (Kumar, 2016) and a local Tamil speaker be invited to come in and discuss the film with the students. Activating the awareness of sound in the learning environment is important (Carey, 2014) and following-up on practising and developing critical listening skills is the objective. Critical listening skills are defined in this cultural context as listening with appreciation, discerning sounds more widely - not being limited to just people, but, for example, listening for the outdoor pumps residents are required to use to fill their water urns.

The visual perceptual skill requires more than 'just seeing', but rather looking, remembering, and appreciating. The video is well-endowed with rich cultural cues and the purpose of viewing the video is to develop the cultural awareness of the student. Questions to consider for the visual aspect include:

- How do the students prepare for school?

- Do they seem eager to go to school?

- How do students get to school?

- What are your observations of the classroom environment?

- What games do students play during school breaks?

Of special note is that the video opens with a street scene leading to Jenolin's (one of the two children featured in the video) home. On the footpath, there is a chalk drawing of a 'star' that could easily be missed in the three seconds of screen time it has, but it is an important link to the spiritual aspect that it represents in the everyday experience of Indian culture: the Mandala, a graphic image drawn to evoke the link of the spiritual to the environment. Further significance may be drawn from the image of the 'star' being drawn in chalk with reference to the impermanence of the symbol, and life. The Mandala is a good example of the rich significance that may be part of each frame of the video and may only come to life when the observer is aware of its existence and meaning and acknowledges and respects it for what it is. Whilst the Mandala symbol can take the discussion on a rich tangent, it is important to develop perceptual skills to purposefully observe and register visual cues and interpret their significance. In the school setting for example, it is culturally important for the children to sit with their teacher and eat lunch prepared from their homes. The importance of family and community is essential in Indian culture. Another obvious observation are the traditional sarees worn by the teacher or the dot on the forehead for example.

Tactile skill development offers different silent nuances that may not be noticed at first. The video shows an 'Indian' sense of the tactile component of perceptual learning. Examples include the way the mother feeds the school aged child, and the way that the parents frequently and repeatedly touch their children with displays of affection. This behaviour may be contrasted with some 
cultures where the sense of touch may be limited, restricted, and less frequently displayed in public.

\section{LOOKING BACK AND THINKING FORWARD}

Within ITE programmes there are no recipes for the cultural preparation of ITE students embarking on international practicums. Whilst ITE students live in a culturally diverse multicultural Australia, they do not necessarily have the cultural competencies to teach in distant lands (Moran, 2016; Santoro, 2009). We agree with Santoro (2013) that a pre-practicum tourist experience must be avoided when preparing students for internationalist practicums. Rather, a predeparture preparation needs to include conversations about the host country, coupled with academic readings on intercultural education.

Among Richard's Australian students were white students who reported that their Indian students accorded them celebrity status, and even the mentor/supervising teacher saw them as having all the answers. Whilst ITE students gained some Eastern ideas of how to teach, they commented on how their predominantly Western-style teaching was well received by the local students who loved "not having to learn by rote", "making things", "playing games", "going outside of the classroom to learn", and "going on their first ever excursion to the shops to teach them Maths". The ITE students commented on the adherence to examinations in the classroom and found the rote learning to be especially stifling and difficult to work with from a teaching perspective (Johnson, 2009).

We contend that a video like A Day in the Life... of Tamil School Children' when used in the pre-departure context of preparing to teach in an unfamiliar cultural setting, would help position ITE students to learn about the local culture, and how to teach in that particular context. In the pilot showing of the video, the most common response from the ITE students was "if you had not pointed it out, I wouldn't have noticed the importance of prayer". Religious beliefs are deeply rooted in Indian culture, and the ITE students found "it is interesting that everything seems to have meaning, often there are religious links" attached to day to day living. Education is highly valued in Indian society; thus children being prepared for class is essential. Suhela is depicted in the video as being studious, having acquired many trophies and prizes. For her and her family "studying before going to school was important". It appears she is conscious of not bringing shame to the family. The school advertises 'matriculation', which is an important cultural aspiration for the children. The ITE students thought that the parents pampered their children; some recognised that cultural issues are "a lot deeper"; they noticed home prepared cooked meals eaten for lunch at school. In viewing the video, the ITE students noticed the cultural acceptance of "overcrowding in the rickshaw" for example. They also noticed cultural perceptions of the conditions of the environment which they may consider "run down" compared to what they are familiar with.

The video therefore serves to foster respect and intercultural understandings of Eastern settings. Where students learn of other cultures, they learn from them and with them. Students who took part in previous international practicums reacted positively to the question: Would the video 'A Day in the Life... of Tamil School Children' have improved your pre-departure preparation for the international practicum? They mentioned that such a video would have 
better prepared them to learn from an overseas teaching experience. Moreover, they regretted not being given such a learning focus prior to their departure. They agreed that the video may be used as an effective tool for cultural familiarisation, especially when woven into a pedagogy preparing students to embrace the opportunity to learn in a rich cultural environment. These interim results are encouraging and demonstrate that video methodology can encourage better understanding of intercultural learning. The use of video methodology as pre-departure preparation enables ITE students to learn from the experience as opposed to just enjoying the exotic differences as a tourist might.

Tertiary ITE educators are encouraged to develop and use visual resources to enable ITE students to observe and appreciate differences. ITE students can benefit from cultural scaffolds as offered by the example of video methodology presented here in preparation for international practicum. We found that perceptual learning is often ignored or taken for granted in preparing ITE students for their overseas classroom experiences. A multimedia resource such as a video can enable perceptual learning, cultivating intercultural understandings to assist ITE students prior to international placements. While the video in this discussion focuses on ITE students, it may be used as a point of discussion in other courses that explore creating respectful intercultural understandings, one in which students value their own culture, language and beliefs, while engaging positively with the cultures of others. The video offers students the chance for "them to consider their own beliefs and attitudes in a new light, and so gain insight into themselves and others" (ACARA, 2020).

\title{
FINAL REMARKS
}

The COVID-19 global pandemic presents the opportunity to reflect on past experiences of internationalising ITE curriculum (Joseph \& Johnson, 2020). During COVID-19 travel bans, this video became an effective visual pedagogy enabling ITE students to build their local and international cultural understanding and embrace diversity, while also developing their perceptual learning. We acknowledge the tensions existing between globalisation and nationalisation, between building walls and closing borders. By promoting a rich curriculum that is culturally inclusive and respectful of diverse cultural practices ITE students may develop a 'pedagogy of respect' in schools (Johnson, 2006). The video discussed in this article was effectively used to promote and enhance intercultural knowledge, interactions, and cultural exchanges. Sharing of intercultural knowledge is hopefully a broadening experience for ITE students, empowering them to work respectfully with culturally diverse students locally and internationally. Ongoing professional development in this area is recommended to better prepare staff and ITE students for culturally diverse practicum settings.

\author{
Manuscript Submitted: August 9, 2020 \\ Manuscript Revised: September 9, 2020 \\ Manuscript Accepted: September 29, 2020
}




\section{REFERENCES}

Abraham, M. (2017, September 4). Dark is beautiful: the battle to end the world's obsession with lighter skin.

https://www.theguardian.com/inequality/2017/sep/04/dark-is-beautifulbattle-to-end-worlds-obsession-with-lighter-skin

Australian Curriculum (ACARA). (2020). Intercultural understanding. https://www.australiancurriculum.edu.au/f-10-curriculum/generalcapabilities/intercultural-understanding/

Australian Institute of Teaching and School Leadership (AITSL). (2020). Australian Professional Standards for Teachers. https://www.aitsl.edu.au

Besley, T., \& Peters M.A. (Eds.) (2012). Interculturalism, education and dialogue. Peter Lang.

Blomberg, G., Sherin, M.G., Renki, A., Glogger, I., \& Seidel, T. (2014). Understanding video as a tool for teacher education: investigating instructional strategies to promote reflection. Instructional Science, 42(3), 443-463. https://doi 10.1007/s11251-013-9281-6

Bodycott, P. (2009). Choosing a higher education study abroad destination: What mainland Chinese parents and students' rate as important. Journal of Research in International Education, 8(3), 349-373. http://doi: 10.1177/1475240909345818

Brandimonte, M., Gilles, O. E., \& McDaniel, M.A. (1996). Prospective memory: Theory and applications. Psychology Press.

Bridges, S., \& Bartlett, B. (2005). At the crossroads of culture and nation: International education and training in English. Stimulating the Action as Participants in Participatory Research, 1(1), 99-112.

Bulman, C., \& Schutz, S. (2004). Reflective practice in nursing. Blackwell Publishing.

Carey, B. (2014). How we learn: The surprising truth about when, where, and why it happens. Random House.

Carter, P.L., \& Darling-Hammond, L. (2016). Teaching diverse learners. In D. H. Gitomer \& C.A. Bell (Eds.), Handbook of research on teaching (5th ed), American Educational Research Association.

Chalfen, R. (2011). Looking two ways: Mapping the social scientific study of visual culture. In L. Pauwels \& D. Mannay (Eds.), The SAGE handbook of visual research methods (pp. 37-56). SAGE.

Clandinin, D. J., \& Connelly F. M. (2000). Narrative inquiry: experience and story in qualitative research. Jossey-Bass.

Comet, L. T. M. (2018). Visual narrative data-driven storytelling. ACM

Transactions on Multimedia Computing, Communications and Applications, 1(1), 1-20.

https://www.researchgate.net/profile/Lina Teresa Molinas Comet/publicat ion/343041524 Visual Narrative Data-

Driven Storytelling Seminar Paper/links/5f12e0ee299bf1e548c0d030/Vis ual-Narrative-Data-Driven-Storytelling-Seminar-Paper.pdf

Council of Europe. (2008). Intercultural dialogue: living together as equals in dignity. White Paper. Committee of Ministers, Council of Europe.

Davis, S. E. (2007). Learning styles and memory. Institute of Learning Style Research Journal, 1, 46-51. 
Deardoff, D.K. (2020). Manual for developing intercultural competencies: story circles. Routledge

de Wit, H. (2019). Internationalization of higher education, a critical view. Simon Fraser Educational Review, 19(3). 9-17. https://doi.org/10.21810/sfuer.v12i3.1036

de Wit, H. (2020). Internationalization of higher education. Journal of International Students, 10(1), i-iv. https://doi.org/10.32674/jis.v10i1.1893

Dewey, J. (1963). Experience and education. Collier Books.

Dhillon, A. (2012, May, 23). The Indian obsession with fairer skin sinks to a new low. The Age. http://www.4thmedia.org/2012/05/the-indian-obsession-withfairer-skin-sinks-to-a-new-low/

Diller, J. V., \& Moule, J. (2005). Cultural competence: A primer for educators. Thomson/Wadsworth.

Feenberg, A. (1995). Alternative modernity: The technical turn in philosophy and social theory. University of California Press.

Frawley J., Russell G., Sherwood J. (2020). Cultural competence and the higher education sector: A journey in the academy. Springer.

Gardner, H. (2006). Multiple intelligences: New horizons. Basic Books.

Gay, G. (1993). Building cultural bridges: A bold proposal for teacher education, Education and Urban Society, 25(3), 285-299.

Holland, D.C., Lachicotte, W. jr., Skinner, D., \& Cain, C. (1998). Identity and agency in cultural worlds. Harvard University Press.

Howard, T. C., \& Aleman, G. R. (2008). Teacher capacity for diverse learners. In M. Cochran-Smith, Handbook of research in teacher education: Enduring questions in changing contexts ( $3^{\text {rd }} \mathrm{Ed}$.). Routledge.

Hull, G. A., Stornaiuolo, A., \& Sahni, U. (2010). Cultural citizenship and cosmopolitan practice: Global youth communicate online. English Education, 42(4), 331-367.

Jackson, J. (2018). Intercultural interventions. In J. Jackson (Ed), Interculturality in international education (pp. 129-156). Routledge.

Johnson, R. (2009, June, 28-1 July). Developing intercultural teachers: The Mumbai global experience project. [Paper presentation] Australian Teacher Education Association Conference. Albury, New South Wales. https://files.eric.ed.gov/fulltext/ED524563.pdf

Johnson, R. (2017). 'A day in the life... of Tamil school children'. https://youtu.be/vPdiogRR-lg.

Johnson, R., \& Jumani, N. B. (2009). Building cross cultural understandings through e-chatter. Indian Journal of Open Learning, 18(1), 17-27.

Joseph, D. (2003). An African music odyssey: introducing a cross-cultural music curriculum to Australian primary teacher education students. Music Education International: Journal of the International Society for Music Education, 2(1), 98-111.

Joseph, D. (2010) Locating boundaries, different rhythms to the same name. In M. Kumar, S. Pattanayak \& R. Johnson (Eds.), Framing my name: extending educational boundaries (pp. 47-59). Common Ground Publishing.

Joseph, D. (2016). Promoting cultural diversity: African music in teacher education. Australian Journal of Music Education, 50(2), 98-109. 
Joseph, D., \& Human, R. (2009). African music: negotiating a space in contemporary society. Intercultural Education, 20(4), 359-370. https://doi.org/10.1080/14675980903351995

Joseph, D., \& Johnson, R. (2019). Colour, culture and difference in Australian teacher education: voices from the edge. Qualitative Research Journal, 19(3), 324-343. http://doi: 10.1108/QRJ-12-2018-0010

Joseph. D., \& Johnson, R. (2020). Studying abroad while staying at home in Australia: Diverse intercultural learning and teaching through partnerships. In S. Kommers \& K. Bista (Eds.), Inequalities in study abroad and student mobility: Navigating challenges and future directions (pp.140-155). Routledge.

Joseph, D., Nethsinghe, R., \& Cabedo-Mas, A. (2018). Creating multicultural music opportunities in teacher education: Sharing diversity through songs. Australian Journal of Teacher Education, 43(5), 31-47. http://dx.doi.org/10.14221/ajte.2018v43n5.3

Kember, D. (2001). Reflective teaching and learning in the health professions. Blackwell Science.

Knight, J. (2004). Internationalization remodeled: Definition, approaches, and rationales. Journal of Studies in International Education, 8(1), 5-28. http://doi: 10.1177/1028315303260832

Kumar, M. (2016). 'Dharmadurai'. http://www.desimartini.com/reviews/dharmadurai/md4888.htm.

Ladson-Billings, G. (2001). Crossing over to Canaan: The journey of new teachers in diverse classrooms. Jossey-Bass.

Leeds-Hurwitz, W. (2013). Intercultural competences: Conceptual and operational framework. UNESCO. https://unesdoc.unesco.org/ark:/48223/pf0000219768

Mannay, D. (2015). Visual, narrative and creative research methods: Application, reflection and ethics. Routledge.

Marginson, S., \& Considine M. (2000). The enterprise university: Power, governance and reinvention in Australia. Cambridge University Press.

Mookerji, R. (1969). Ancient Indian education. Motilal Banarsidass.

Moran, A. (2016). The public life of Australian multiculturalism: Building a diverse nation. Springer.

Noetel, M., Griffith, S., Delaney, O., Sanders, T., Parker, P., del Pozo Cruz, B., \& Lonsdale, C. (2020). Video improves learning in higher education: A systematic review. https://doi.org/10.31234/osf.io/kynez

O'Brien, K. (2016, December, 3). Why are our arts offerings so whitebread? The Age. https://www.theage.com.au/entertainment/why-are-our-arts-offeringsso-whitebread-20161129-gszzqk.html

Pauwels, L., \& Mannay, D. (2020). The Sage handbook of visual research methods. SAGE.

Reagan. T. (2000). Non-western educational traditions alternative approaches to educational thought and practice. Lawrence Erlbaum Associates.

Ridgway, A., Li L., \& Quinones, G. (2016). Visual narrative methodology in educational research with babies: triadic play in babies room. Video Journal of Education and Pedagogy, 1(1), 1-18. https://doi.org/10.1186/s40990-016-0005-0 
Rizvi, F. (2010). Working with diversity in transnational contexts. Policies and practices for teaching socio-cultural diversity. Council of Europe Publishing.

Rogoff, B. (2003). The cultural nature of human development. Oxford University Press.

Rosenblum, L. D. (2010). See what I'm saying: The extraordinary powers of our five senses. W.W. Norton \& Company

Santoro, N. (2013). 'If I'm going to teach about the world, I need to know about the world': developing Australian pre-service teachers' intercultural competence through international trips. Race Ethnicity and Education, 17(3), 429-444. https://doi.org/10.1080/13613324.2013.832938।

Santoro, N. (2009). Teaching in culturally diverse contexts: What knowledge about 'self' and 'others' do teachers need? Journal of Education for Teaching, 35(1), 33-45. https://doi.org/10.1080/02607470802587111

Schön, D. (1983). The reflective practitioner. Temple Smith.

Scott, P. (1998). Massification, internationalisation and globalization. In P. Scott (Ed.), The globalization of higher education. Open University Press.

Sherin, M.G., \& Russ, R. (2014). Teacher noticing via video: The role of interpretive frames. In B. Calandra \& P. Rich (Eds.), Digital video for teacher education: Research and practice. Routledge.

Smith, A. (2014, April, 27). Sydney named top destination in the world for international students. The Sydney Morning Herald. https://www.theage.com.au/national/nsw/sydney-named-top-destinationin-the-world-for-international-students-20140424-zqz2a.html

Terry, B. (2000). Areas of perception that affect learning. https://web.archive.org/web/20030218142452/http://www.parentpals.com/ gossamer/pages/Detailed/890.html

Topsfield, J. (2016, August, 15), Research finds many Australians negative and ill-informed about Indonesia. The Age.

https://www.smh.com.au/world/research-finds-many-australians-negativeand-illinformed-about-indonesia-20160814-gas6z3.html

Ukpokodu, O. (2011). Developing teachers' cultural competence: One teacher educator's practice of unpacking student culturelessness. Action in Teacher Education, 33(5-6), 432-454. https://doi.org/10.1080/01626620.2011.627033

Walker, E.B. \& Boyer, D.M. (2018). Research as storytelling: the use of video for mixed methods research. Video Journal of Education and Pedagogy, 3(8), 1-12. https://doi.org/10.1186/s40990-018-0020-4 


\section{ABOUT THE AUTHOR(S)}

\section{DAWN JOSEPH}

Deakin University, Melbourne, Australia

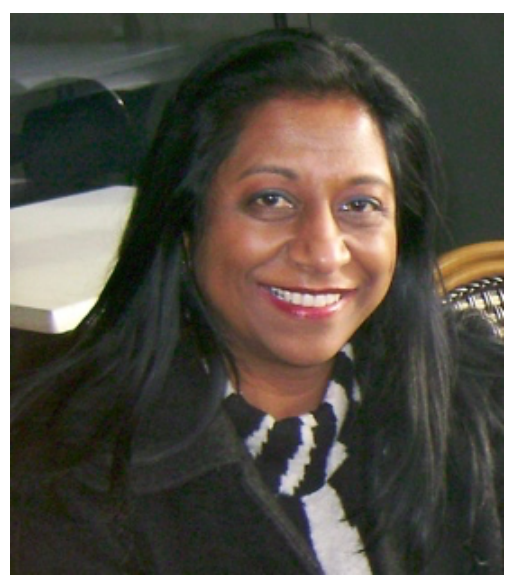

Dr Dawn Joseph is an Associate Professor in Music Education in the Faculty of Arts and Education at Deakin University (Melbourne, Australia). She teaches in both undergraduate and postal graduate programmes in the School of Education. Dawn's international and national programme of research and scholarship includes higher education, teacher education and music. She is recognised locally and internationally in her focus areas of music education, African music, multicultural music, community music, and ageing and wellbeing in the Arts.

\section{RICHARD JOHNSON}

\section{RMIT University, Melbourne, Australia}

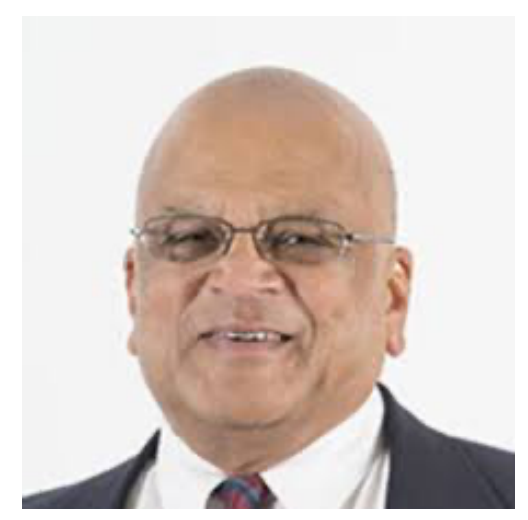

Dr Richard Johnson is a Senior Lecturer in the School of Education, RMIT University (Melbourne, Australia). He currently teaches in undergraduate and postgraduate programmes. Richard's research and teaching interests include intercultural teaching and learning preparing initial teacher education students to make the transition to the profession.

The opinions expressed are those of the author(s) and not the New Zealand Journal of Teachers' Work. Copyright is held by individual authors but offprints in the published format only may be distributed freely by individuals provided that the source is fully acknowledged. [ISSN-1176-6662] 